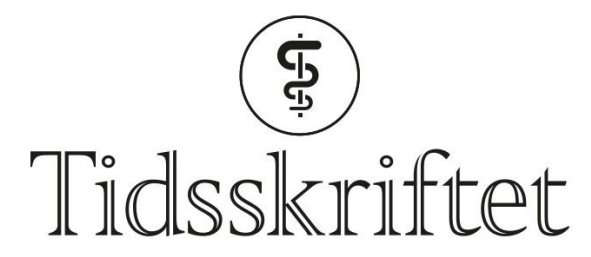

DEN NORSKE LEGEFORENING

\title{
Fortelling som kritikk
}

ESSAY

KETIL SLAGSTAD

Lege og medisinsk redaktør i Tidsskriftet

Medisinens historie er en historie om vilje til liv - men også en fortelling om vilje til makt og vilje til viten.

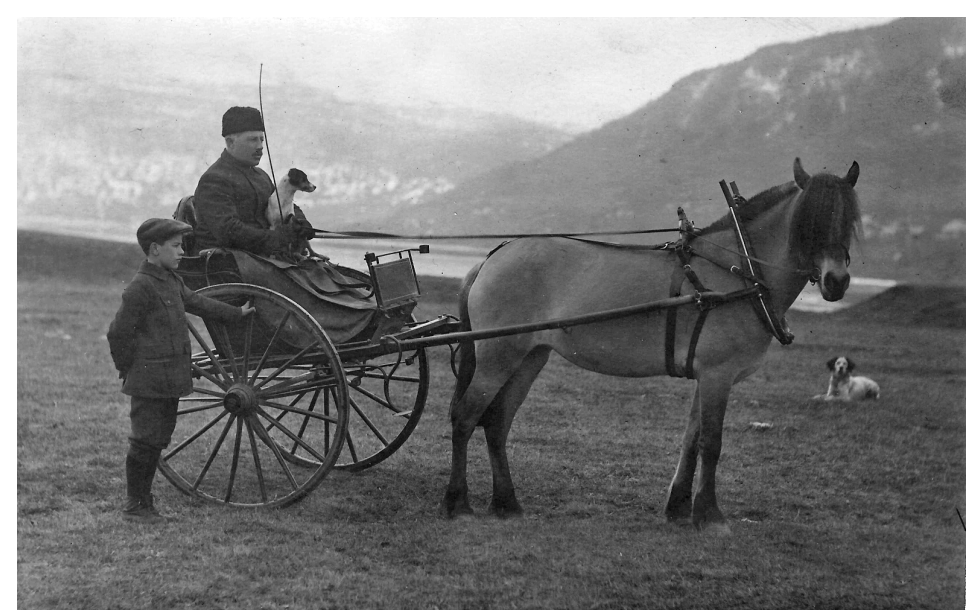

Distriktslege på Voss, Birger Lcerum (1872-1953), med eldstesønn Ole Didrik (1901-72). Livet som distriktslege var et livsvalg, ikke bare for legen, men også for legekona, som gjorde husarbeid og hjalp til i legearbeidet. Foto: Ole Didrik Lcerum

Aina Schiøtz, som er professor i medisinsk historie ved Universitetet i Bergen, er ikke redd for å gi seg $\mathrm{i}$ kast med de store historiske linjer. Hun har alt publisert to omfattende studier, Doktoren. Distriktslegenes historie 1900-1984 (1) og Det offentlige helsevesen i Norge 1603-2003 (forfattet sammen med Ole Georg Moseng) (2). Nå foreligger hennes store medisinhistoriske verk Viljen til liv. Medisin- og helsehistorie frå antikken til vår tid. Dette er den første læreboken i medisinsk historie som foreligger på norsk siden 1936, da Medisinens historie i Norge av Reichborn-Kjennerud, Grøn og Kobro ble utgitt (3).

Tittelen vitner om et ambisiøst - nær sagt halsbrekkende - prosjekt: Kan man skrive, ikke bare medisinens, men hele helsens historie i én sammenfatning? Schiøtz forklarer innledningsvis at prosjektet ble født da forlaget kontaktet henne for å skrive en bok om medisinsk historie på 128 sider for historiestudenter. Det endelige verket er drøyt fire ganger så langt - med et omfattende noteapparat og litteraturliste. Likevel: Det sier seg selv at til og med dette formatet ville vært for kort for å innfri tittelens lovnader. Det blir da også raskt klart at forfatteren har gjort visse vesentlige avgrensninger. For det første tar hun i brorparten av boken for seg de siste par århundrenes historie. For det andre konsentrerer hun seg om vestlig medisin. 


\section{Fra kroppsvæsker til celler og bakterier}

Boken er delt i fem. I første del ser Schiøtz på forskjellige tiders sykdomsforståelse, praksis og vitenskap. Hun tar utgangspunkt i humorallæren og Galens (ca. 129-217 e.Kr.) syn på naturen som formålstjenlig, lovmessig og meningsskapende.

Gjennom obduksjon av dyr, og inspirert av Aristoteles' (384-322 f.Kr.) vektlegging av det observerbare og empiriske, var mye av grunnlaget lagt for et kunnskapsparadigme som skulle dominere helt frem til renessansen: Empiri og metafysikk gikk hånd i hånd.

I renessansen vant en mer eksperimentell metodikk frem. Obduksjon og disseksjon av mennesker ble vanligere, og det førte til utbygging av anatomiske teatre i flere europeiske byer. Disse var bygd etter modell fra amfiteatrene. Disseksjonen fant sted på et bord i midten, og sirkelformede rader var organisert oppover i høyden for at tilskuerne skulle ha god oversikt. København fikk sin anatomisal i 1645, der henrettede forbrytere ofte ble lagt på bordet: «Disseksjon vart straff, og straffa heldt fram etter døden.» Disseksjonen gjorde noe med vårt syn på kroppen. Kroppen ble degradert fra noe hellig til noe som kunne skjæres i. Like fullt var kroppen også estetikk, skriver Schiøtz, en mesterlig manifestasjon av gudommelig visdom. Det var altså en dualitet eller ambivalens i synet på kroppen.

I det 17. århundre ble en mer mekanistisk og reduksjonistisk forståelse av kroppen, i tråd med Descartes' (1596-1650) filosofi, rådende. Det var ikke lenger mennesket som var sykt, men kroppen eller organet. Tankegangen har stått sentralt for senere endringer i medisinsk tenkning i det 19. århundre - som igjen har hatt stor betydning for hvordan vi tenker om sykdom i dag.

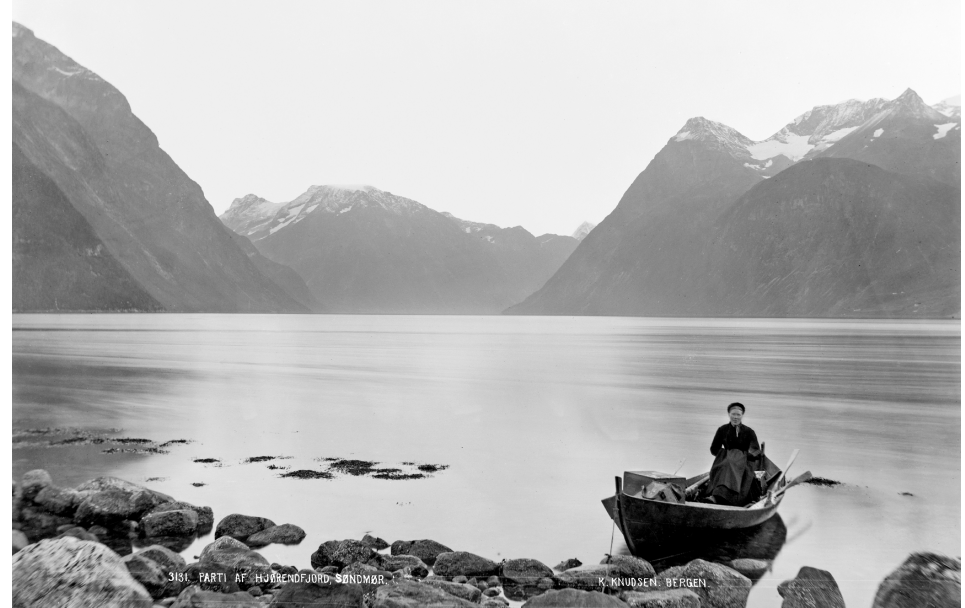

Pernille Maria Trulsdotter Scebønes (1824-1902) i gjerningen som distriktsjordmor. Hun jobbet hele sitt liv som jordmor i Hjørundfjord jordmordistrikt på Sunnmøre. Distriktsjordmortradisjonen døde sakte ut fra 196o-årene, da fødslene i økende grad fant sted på sykehus og fødestuer. Foto: Knud Knudsen, Universitetsbiblioteket i Bergen, Billedsamlingen

Hvordan påvirket dette Norge? På 160o- og 1700-tallet var det bare en håndfull leger i Norge, og de etterlot seg få skriftlige kilder. Vi vet altså ikke så mye om de vitenskapelige gjennombruddene som ble gjort i renessansen og i tidlig nytid i deler av Europa, fikk rotfeste i norsk medisin. Ifølge boksamlingen til tre leger utdannet rundt 1700 er det mye som tyder på at de var internasjonalt orientert, særlig mot tysk og nederlandsk medisin.

Hôtel-Dieu var et stort sykehus i sentrum av Paris som sto sentralt i etableringen av hospitalmedisinen for et par århundre siden. Sykehuset er et av verdens eldste, etablert i det 7. århundre. Det store antallet pasienter, på grunn av sårede i revolusjonen og Napoleonskrigene og tilflytting til byen som følge av industrialiseringen, ga et godt grunnlag for å registrere og kvantifisere observasjonene. Det var også beryktet for å være fullstendig overfylt: «Det kunne liggje opptil åtte personar i same seng, fire kvar veg.» (s. 185). 
I tråd med opplysningstidens filosofi, bort fra metafysikken, ble direkte observasjon det rådende ideal: både fysisk undersøkelse gjennom presis beskrivelse av tegn-ikke minst gjennom bruk av nytt utstyr som stetoskopet (konstruert i 1816) og mikroskopet (som allerede var i bruk, men nå ble forbedret) - og patoanatomisk undersøkelse gjennom obduksjon. Idealet var peu lire, beaucoup voir, beaucoup faire (fransk for les lite, se mye, gjør mye). Schiøtz skriver: «Reint konkret flytta legen blikket frå det ytre og overordna til kroppens indre, til det enkelte organet og til vevet.» (s. 50-52). Man kan legge til at man i tillegg flyttet blikket vekk fra pasientens egne opplevelser. Dette brøt fundamentalt med den galenske læren om de fire kroppsvæskene og en sykdomsforståelse knyttet til et begrep om dyskrasi og humoral ubalanse. Grunnlaget for nåtidens sykdomsoppfatning ble lagt allerede her: Ved å betrakte sykdom som et avgrenset og klassifiserbart fenomen ble moderne nosologi født. Med det var basis også lagt for spesialisering av legene, for eksempel innen patologisk anatomi, pediatri, venerologi og psykiatri.

Den franske revolusjonen (1789-99) knyttet legene nærmere til staten, gjennom utdanning og kontroll av praksis. Det tradisjonelle skillet mellom medisin som høystatus universitetsdisiplin, og kirurgi som laugsorganisert barberyrke, etablert allerede i middelalderen, ble opphevet. Medisinerundervisningen ved Det Kongelige Frederiks Universitet som startet i 1814 (universitetet ble grunnlagt i 1811), var et forent medisinskkirurgisk studium (4). I 1815 ble et anatomikammer, senere Anatomisk institutt, åpnet undre professor Michael Skjelderup (1769-1852) ved Det Kongelige Frederiks Universitet. I studieplanen het det: «Den for Lægen saa nødvendige Videnskab [anatomi] dyrker han ei alene ved at høre Forelæsning derover, men ogsaa ved flittigen at dissikere Cadavera....) (s. 53).

I annen halvdel av 18oo-tallet var det Berlin og deriblant patologen Rudolf Virchow (1821-1902) som sto i medisinens midte. Cellulærpatologien og laboratoriemedisinen nye idealer for legen. Årsakene til sykdommene skulle ikke søkes i vevene, men dypere, i cellene. Dette førte til en ytterligere objektiverende tildreining av lege-pasient-forholdet: «I den nye fasen fanst det knapt nok stad noko personleg møte mellom det sjuke mennesket og den medisinske forskaren. Sjukdom vart einsidig betrakta som ein fysisk-kjemisk prosess som berre kunne forklarast i tråd med fasttømra naturvitskaplege lover. I utforskinga av desse prosessane var oppgåva til pasienten i beste fall å levere analysemateriale, men som regel var det forsøksdyr som tente føremålet.» (s. 58)

Schiøtz’ overblikk tydeliggjør hvordan forskjellige historiske perioder har hatt betydning, ikke bare for dagens sykdomsforståelse og for profesjonsdannelsene, men også for legepasient-forholdet.

Det 2o. århundre var preget av massiv ødeleggelse og håpløshet, men var også århundret for store medisinske gjennombrudd. Røntgenapparatet ble lansert i 1895 . Sekretin var det første hormonet som ble identifisert i 1902. Penicillin ble oppdaget alt i slutten av 1920årene, men masseprodusert først etter krigen. Hun vokter seg imidlertid vel for å lese fremskrittene fra et utelukkende teleologisk perspektiv, forstått som at historien kun har én retning og mål, nemlig dagens kunnskapsforståelse. Selv om en gradvis reduksjonistisk vending innen medisinen - kanskje helt tilbake til 16oo-tallet - har ført til mange fremskritt, understreker hun at mye har skyldtes flaks og tilfeldigheter, som penicillin og ciklosporin A. Ytre samfunnsmessige forhold har også spilt en rolle, den annen verdenskrig var for eksempel et godt utgangspunkt for å prøve ut penicillin på sårede soldater.

Schiøtz har dedikert et eget kapittel til psykiatriens historie. Her stiller hun forsiktige spørsmål om vi i dag ser tegn til en ny biologisering av faget, med henvisning til den første bølgen på slutten av 18oo-tallet under den tyske psykiateren Emil Kraepelin (1856-1926). Hun sikter til overforbruk av psykofarmaka. Schiøtz nevner at den biopsykososiale modellen, som ble lansert mot slutten av 1970-årene, ofte blir trukket frem som et eksempel på at man har lyktes med å integrere biologisk kunnskap, for eksempel fra nevroradiologi og genetikk, med psykologi og kunnskap om sosiale forhold. Her kunne det vært på sin plass med litt historisk kritisk arkeologi: I hvilken kontekst oppsto modellen, og hvilke utfordringer i 
psykiatrien forsøkte den å besvare? I hvilken grad biopsykososial tenkning lyktes med å endre hvordan vi relaterer oss til og behandler pasientene? Det må vel være det sentrale, om biopsykososialbegrepet ikke bare skal bli et honnørord i festtaler.

\section{Rectum som grav}

I kapitlet om arvelære og genetikk trekkes sammenhengen mellom sosialhygiene, arvehygiene og rasehygiene. Det informerer dagens diskusjon om fosterdiagnostikk og selektiv abort. Kapitlet spiller inn i førsommerens store bioetiske debatt om hva som er et «fullverdig liv», ikke minst om hva som skiller et statlig fosterdiagnostisk program fra et eugenisk prosjekt.

Det er også helt riktig, som Schiøtz påpeker, at vi mangler en sammenfattende medisinskhistorisk studie om hiv/aids på norsk. Derfor er det underlig at hun i forklaringen på hvorfor epidemien har vært vanskelig å stoppe, velger å støtte seg til spekulative teorier («unge menn rett og slett søkjer ubeskytta sex, gjerne med menn som er ein god del eldre, for å bli tekne opp i «fellesskapet» (...) homofile menn ser at dei vanskeleg kan føre slekta vidare, dei representerer så å seie «endestasjonen» og er derfor mindre tilbakehaldne med omsyn til risikoåtferd (...) ei tredje tilnærming handler om dødsdrift eller forakt for livet») (s. 169-170). Med referanse til siste påstand henviser hun til litteraturteoretikeren Leo Bersanis essay Is the rectum a grave? Schiøtz har her oversett et sentralt poeng hos Bersani. Aids måtte ikke føre til at skeive sluttet å problematisere konvensjonelle samlivsformer mellom menn og kvinner slik som monogamiet. Barsani hadde et politisk budskap om at skeive ikke måtte slutte å dyrke andre samlivsformer :"gay men (...), should resist being drawn into mimicking the unrelenting warfare between men and women, which nothing has ever changed.» (5). Essayet ble skrevet i 1987, altså i en tid preget av sterke moralistiske synspunkter på ikke-heteroseksuell sex, promiskuitet og homser. Metaforen spiller på at rectum, som er assosiert med passiv (les: feminin) homoseksuell seksualitet, truer maskulinitetsidealet. Bersanis poeng var at analsex derfor burde feires for sitt frigjørende potensial - til beste for vår felles seksualitet. For hivaktivistene i USA i 1980-årene var det viktig å fremme sikker sex, for eksempel bruk av kondom, og ikke problematisere promiskuitet i seg selv (7).

Man trenger imidlertid ikke å støtte seg til kritisk litteraturteori for å finne forklaringer. Det finnes mye empirisk forskning på hvorfor hivepidemien har vært vanskelig å stanse. Ønsket om nærhet og å formidle tillit til partner ved ikke å bruke kondom er én faktor (6). Man bør kanskje spørre seg hvorfor det generelt er vanskelig å få folk til å bruke kondom, ikke bare menn som har sex med menn? Epidemien har forskjellige drivfaktorer, avhengig av hvilken kontekst man unders $\varnothing$ ker: I $\emptyset$ st-Europa og Sentral-Asia er epidemien $ø$ kende, særlig blant personer som injiserer rusmidler, og det er mangel på skadereduserende, preventive tiltak. I flere deler av verden rammer epidemien fortsatt primært diskriminerte og stigmatiserte grupper (7).

\section{Fra panoptikon til paviljong}

Annen del av boken handler om hospitalet. Hva er et sykehus? Schiøtz påpeker at vi mangler en historisk overgripende sammenfatning på norsk, og at det er mange måter å angripe denne historien på. En innfallsvinkel er å bruke arkitekturteori og -historie for å se hvordan arkitektur og medisin påvirker hverandre. 


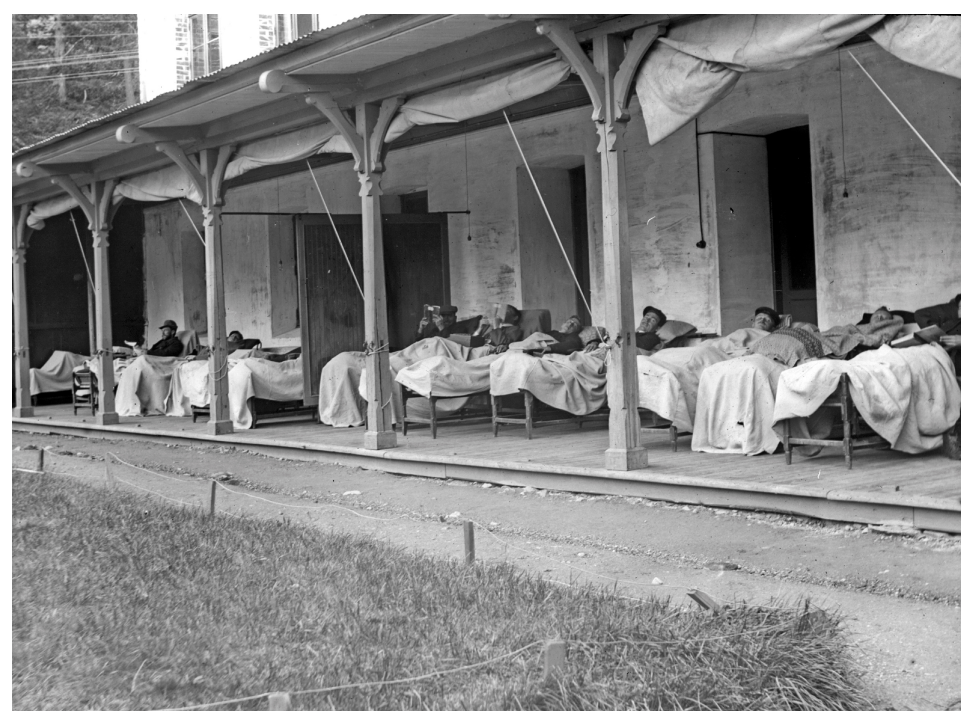

Lyster Sanatorium (Harastølen) for tuberkulosepasienter i indre Sogn ble åpnet i 19o2. Opprinnelig var det 96 sengeplasser. Sanatoriet var plassert i fjellsiden over Luster. Klimaet inne i Lustrafjorden skulle vare gunstig i tilhelingen av sykdommen. Foto: Severin Worm-Petersen, Norsk Teknisk Museum

Arkitekturhistoriker Marit Hvattum har gjort nettopp det, i historien om tilblivelsen av Gaustad sykehus. Utgangspunktet var Frederik Holsts (1791-1871) ideal om at arkitekturen skulle «fremme Anledning til Inspektion og Clasification», formgitt i arkitekt Christian Heinrich Grosch' (1801-65) stråleformede anstalt basert på botsfengselstypen. Panoptikon var idealet: et sentralt punkt hvorfra alt - pasientene - kunne overvåkes. Med tiden skiftet idealene, og det var psykiateren Herman Wedel Major (1814-54) og hans arkitekt Heinrich Ernst Schirmers (1814-87) frittliggende paviljongsykehus som vant frem, påvirket av strømninger i europeisk psykiatri (8).

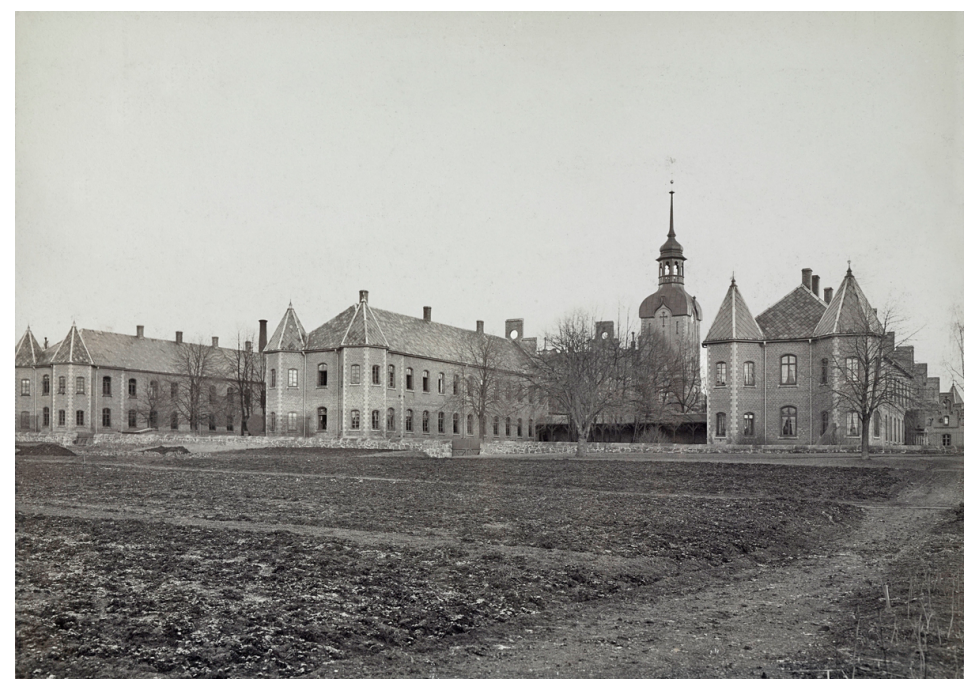

Gaustad sykehus ble etablert i landlige omgivelser, «uberørt av alle ydre Forholde». Sykehuset ble planlagt $i 1845$ og åpnet vel ti år senere. Arkitekturen var et kurativt instrument, ikke lenger straff, men behandling. Sentralt sto tilbaketrekking fra samfunnet og ro for pasientene, og riktig kategorisering og avsondring av ulike pasienter, uavhengig av klasse og hvordan de tedde seg. Dette var nye medisinske idealer omsatt $i$ arkitektur. Paviljongstrukturen knyttes ofte til miasmeteorien, men at den også ble benyttet på Gaustad tyder på at andre idealer lå bak, skriver arkitekturhistoriker Marit Hvattum (7). Foto: Severin Worm-Petersen, Oslo Museum

\section{Risikosamfunnet}

Tredje del av boken handler om folkehelse, epidemiologi, forebygging og vaksinasjon. Schiøtz påpeker at statistikk var i bruk i moderne statsdannelse allerede fra tidlig på 18ootallet. Telling og kvantifisering er et sentralt kjennetegn ved moderne medisin. Noen av de største helsemessige fremskrittene på befolkningsnivå kan tilskrives epidemiologien brukt 
som politisk styringsverktøy: Statistikk ble for eksempel brukt for å bedre boforhold, tilgang til rent vann, vaksinasjon osv.

I annen halvdel av det 20. århundre er det riskofaktorepidemiologien som har tatt styringen gjennom forebygging av hjerte- og karsykdom og livsstilssykdommer. Det har jo også en skyggeside - hvor går grensen? - noe norske allmennleger har vært gode til å problematisere. Her trekker Schiøtz også på filosofen Michel Foucaults begreper om biomakt og biopolitikk, om statens og samfunnets ønske om å regulere borgernes atferd. En viktig observasjon er at sykdom individualiseres, og de strukturelle årsakene til sykdom rykker i baksetet: Man har kun seg selvå takke - og med det følger skyld og skam.

\section{Profesjonen}

Fjerde del av boken er historien om profesjonenes fremvekst, ikke bare legenes, men også sykepleiernes, hjelpepleiernes og jordmødrenes. Kapitlet bør leses av alle leger og gjøres obligatorisk på medisinstudiet. Det er nødvendig i dagens klima, der Spekter gyver løs på den siste rest av hva som gjenstår av faglig autonomi, uten forståelse for at legens gjerning handler om å utøve en profesjon, som igjen henger sammen med en stor grad av delegert tillit.

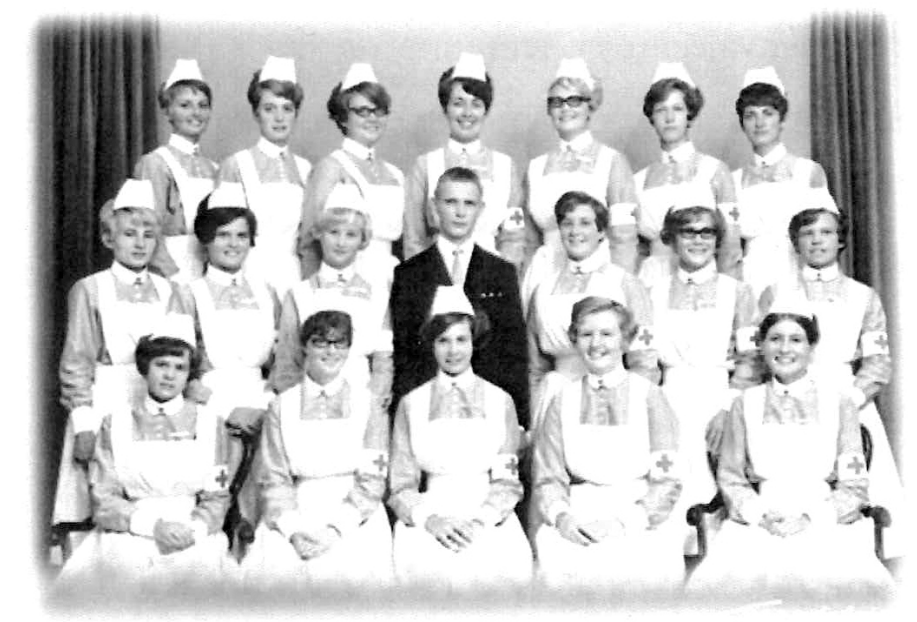

Lov om sykepleie av 1948 ga menn formell tilgang til sykepleierutdanningen. I Rogaland tok det likevel 20 år før første mann var uteksaminert ved Stavanger Røde Kors sykepleierskole kull 2 (1965-68). Foto: Institutt for helsefag, Universitetet i Stavanger

Kapitlet om sykepleiernes profesjonskamp gjennom historien kan kanskje bidra til å utvikle en viss ydmykhet i legekollegiet om vårt felles arbeid med pasientene. Schiøtz er god til å få frem hvilket sprik sykepleierprofesjonen står i mellom omsorgsutøvelse, akademisering og effektivisering.

Bokens siste del handler om nosologi, pasientenes perspektiver og etikk, og Schiøtz understreker at det fremdeles er relativt sett få medisinskhistoriske studier sett fra et pasientperspektiv. Et problem er at kildematerialet kan være sparsomt. Likevel kan man få et indirekte inntrykk via pasientjournalen, og lyrikk og skjønnlitteratur kan være verdifulle kilder til et førstepersonsperspektiv.

Viljen til liv er preget av et svært grundig og omfattende arbeid og vitner om en voldsom kunnskapsmengde hos forfatteren. Boken er en bragd. Den henvender seg til mange - og fortjener også å bli lest bredt. Om jeg skal trekke frem én svakhet, er det at jeg ikke opplever at det blir fortalt en historie, en fortelling. Kanskje må det bli sånn, når man skal ta for over 2 ooo års medisinsk historie. Samtidig gir det å se medisinen under ett en slik mulighet. At boken ikke har et avsluttende kapittel vitner kanskje likevel om at oppgaven har vært vel omfattende? Schiøtz er nøktern i sine betraktninger - hun kunne gjerne vært enda dristigere i sine analyser og trukket linjene lenger for å vise hvordan historien lever i dagens faglige og helsepolitiske diskusjoner. 


\section{Historieløse leger}

Hvorfor skal medisinstudenter, leger og annet helsepersonell i 2017 lese historie? «Mange leger er historieløse», mente Schiøtz i et intervju i Tidsskriftet i 2000 (9). Hun siktet til at leger kan ha godt av å se egne gjerninger og krav i lys av historien, og reflektere over verdigrunnlagene vi baserer våre handlinger på. Spørsmålet er ikke nytt og berører en diskusjon om hva slags fag medisinsk historie egentlig er, og hvilken funksjon det skal ha.

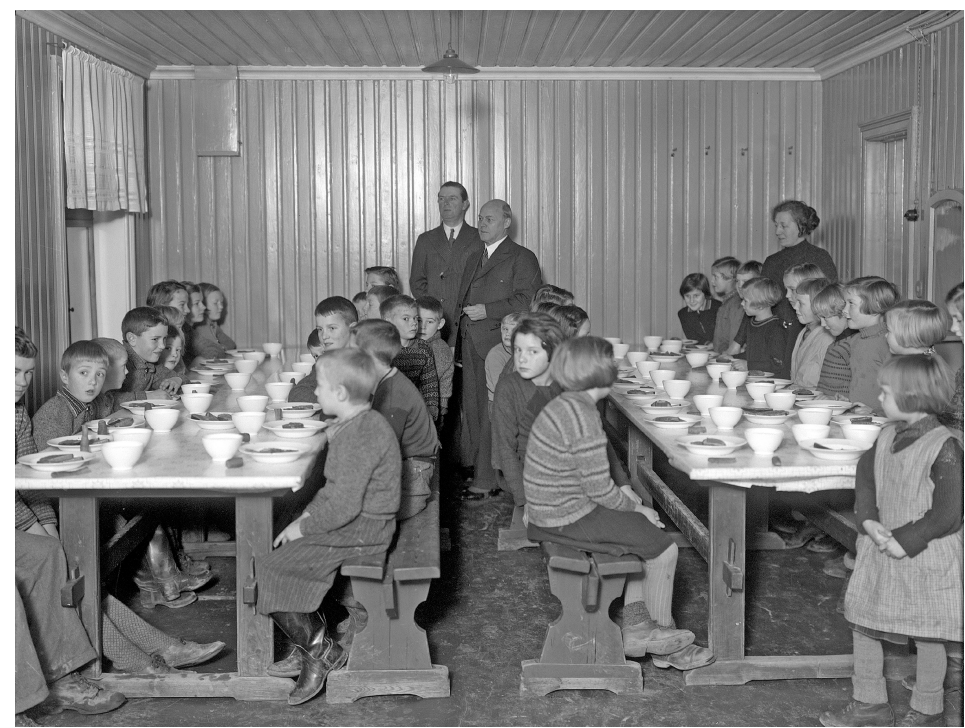

Oslofrokosten var den nye medisinske vitenskapen omsatt i praksis med skolen som styringsinstrument. Satt sammen av Carl Schiøtz (1877-1938), professor i hygiene, ble frokosten et symbol på den nye samfunnshygienen. Frokosten spredte seg over hele landet, her fra Hamar folkeskole i 1934 med skolelege, skoleinspektør og lcererinne i bakgrunnen. Foto: Christian Grundseth, Domkirkeoddens fotoarkiv

Såpass ille syntes Richard Horton, sjefredaktør i The Lancet, det sto til at han under tittelen The moribund body of medical history tegnet bildet av et potensløst fag, der siste rest av kritisk motstandskraft sakte hadde ebbet ut: "So where are the historians of today to illuminate the past as we struggle with the aggressive commercialisation of medicine, failures of professional leadership, notions of free will and death, misuse of medicines, paralysis in public health policy, or catastrophic failures of care? They appear to have evaporated, leaving a residue of dead and inert dust.» (10).

Horton har unektelig et poeng i at vi, trolig mer enn noen gang, trenger kritiske blikk på egen praksis. Selv tenker jeg at det er visse tendenser i moderne medisin som kunne trengt historisk belysning. For eksempel kjennetegnes moderne medisin av at ting går fort - tiden er akselerert - og at effektivitet er blitt et ideal også for legene. Tenk bare på hurtigforløp for pasienter med lårhalsbrudd, hurtigtest for hiv, pakkeforløp for psykiske lidelser og kortest mulig liggetid. Det kunne vært interessant å følge tiden som medisinsk kategori: Når oppsto tanken om at raskere og mer effektivt var bedre? Er dagens effektiviseringspress bare et symptom på en generell akselerasjonstendens i samfunnet, eller har man i medisinen (legene?) selv omfavnet og fremelsket denne tankegangen?

Et annet kjennetegn ved moderne medisin er mulighetens grenseløshet. Vi kan fremskynde og utsette livets begynnelse og slutt. Gjennom fostertesten NIPT kan vi sekvensere hele fosterets DNA og få informasjon om en rekke forhold hos barnet, selv før grensen for selvbestemt abort, som igjen konfronterer oss med spørsmålet om hva slags barn vi ønsker oss. I spørsmålet om eutanasi har leger tatt klare standpunkt. Teknologi og vitenskap påvirker hverandre gjensidig, men hvordan former teknologien vår profesjonsutøvelse og etikk?

Moderne medisin er også preget av informasjonsoverflod. Medisinsk kunnskap akkumuleres, men vi sliter med å holde oss oppdatert på retningslinjer og systematiske oversikter og å kunne oversette informasjonen til møtet med den enkelte pasient. Vi kan telle tilbakelagte 
skritt i løpet av en dag, fettprosent, hvilepuls, søvnmønster og blodtrykk. Men hvordan skal vi bruke informasjonen, gjør den oss klokere, og lever vi bedre liv? Kanskje kommer dette klarest til uttrykk i alle lovnadene om persontilpasset presisjonsmedisin. Det er blitt fremmet som et nytt holistisk prosjekt - gjennom bruk av genomiske og molekylærbiologiske data - nemlig at datamengden på nytt setter individet i sentrum. Bak prosjektet ligger det imidlertid sterke økonomiske interesser i å tjene penger på folks helseangst. Blant annet derfor er prosjektet blitt kritisert for ytterligere å medikalisere livet (11).

\section{Historie som narrativ}

Historikeren står i en posisjon til å kunne påpeke slike overgripende tendenser og problematisere dem ut fra hvilke kontekster de oppstår i, og hvilke spørsmål de søker å besvare. Historikere kan hjelpe oss å forstå hvor våre forestillinger stammer fra. Det innebærer at man ikke behandler medisinen som en enhet, snarere hele tiden å undersøke og stille spørsmål ved oppfatninger og praksiser (12). Det vil si å bruke historien for kritisk å belyse vår tid og dagens praksiser, slik Theodor Puschmann (1844-99), professor i medisinhistorie i Wien, etterlyste i 1889. Han klagde over legenes medisinskhistoriske interesseløshet og talte for en rehumanisering av en medisin han mente var blitt for materialistisk og opptatt av vitenskapelige fremskritt. Virkemidlet var historisk Bildung, (tysk for dannelse) altså noe mer karakterdannende enn ren opplysning eller kunnskapservervelse (13). Enkelte vil hevde at formaningen er like aktuell i dag.

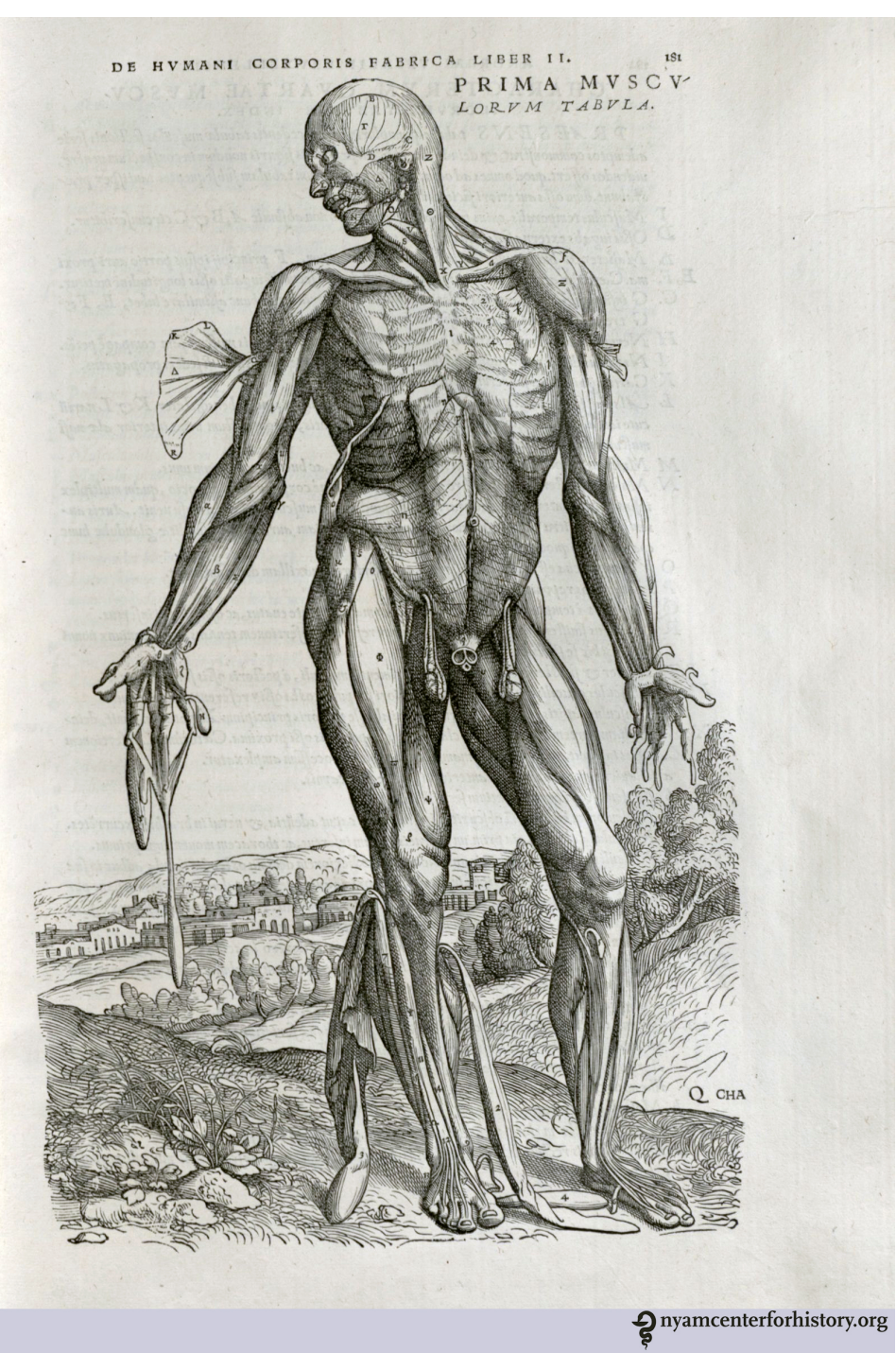

Anatomen Andreas Vesalius' (1514-64) verk De humani corporis fabrica (Om oppbyggingen av den menneskelige kroppen) er et enestående medisinhistorisk verk. Her ser vi en muskelmann $i$ landskapet ved Padova. Verket sier mye om måten man betraktet kroppen på, ikke minst muskulaturen, i renessansen - og kanskje helt frem til vår tid. Tegning: Andreas Vesalius, fra De 
Det forutsetter at man skriver historie, ikke historier. Om man forsker på historie, betyr det at man må forholde seg til primærkilder, oftest trykte kilder i arkiv. Dette arbeidet forutsetter en metode - en åpen, kritisk, spørrende holdning til materialet man møter. Ny kunnskap genererer nye spørsmål. Den kunnskapen man finner, må vektes mot andre kilder. Og kunnskapen må fortolkes.

Den «tradisjonelle medisinhistorien», ofte skrevet av leger, er blitt kritisert for å være selvforherligende, bekreftende og ahistorisk. Kritikken har nok noe ved seg, men debatter om hvem som skal skrive medisinsk historie, ofte mellom faghistorikere og leger med interesse for historie (14), har en tendens til å havne i en lite fruktbar diskusjon om hvem istedenfor den mye mer interessante diskusjonen om hvordan og hvilken funksjon medisinsk historie kan og bør ha (13, s. 3). For en vel så viktig oppgave som å analysere, er å fortelle en historie. Det handler ikke bare om at historien må engasjere om den skal bli lest. Det handler også om å anerkjenne fortellingens mulighetsrom for å skape mer forståelse.

For filosofen Arthur Schopenhauer (1788-186o) var alt i verden vilje til liv. Mennesket er slave av denne viljen, av sin egen natur og livstrang. Det er roten til menneskets lidelse. Det er en ganske annen, mer dystopisk betydning av uttrykket enn hva man kanskje intuitivt ville tenke. Et helt sentralt livsprosjekt er bevisstgjøring om viljen. Kun øyeblikksvis, i møte med skjønnhet, kan vi viljeløst erkjenne viljen. Men for Schopenhauer var det også en annen vei: Ved å vie like stor plass til andres som egen lidelse, overskrides skillet mellom en selv og andre. Denne erkjennelsen stilner viljen. Man blir fri. Kanskje er det det vi må strekke oss etter, på veien gjennom livet - medlidenhet? Et slikt schopenhauersk synspunkt er også et mulig perspektiv på medisinens historie.

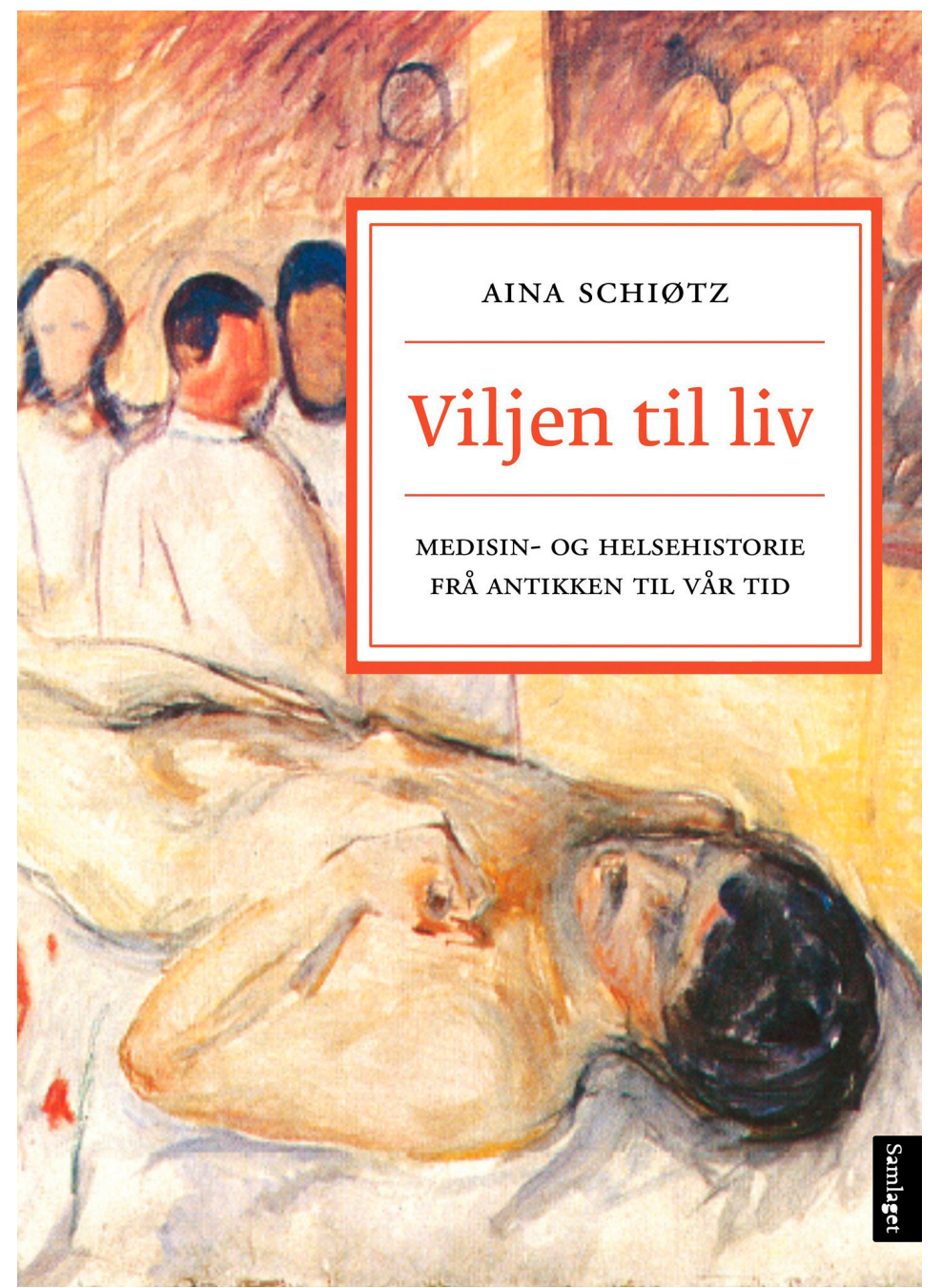

Aktuell bok: Aina Schiøtz. Viljen til liv. Medisin- og helsehistorie frå antikken til vår tid. Oslo: Samlaget, 2017 
1. Schiøtz A. Doktoren. Distriktslegenes historie 1900-1984. Oslo: Pax forlag, 2003.

2. Moseng OG, Schiøtz A. Det offentlige helsevesen i Norge 1603-2003. Bd. 1-2. Oslo:

Universitetsforlaget, 2003.

3. Reichborn-Kjennerud I, Grøn F, Kobro I. Medisinens historie i Norge. Oslo: Grøndahl, 1936.

4. Haave P. Medisinens kirurgisering og etableringen av en norsk legeskole i 1814. Tidsskr Nor Legeforen 2009; 129: 2637 - 41. [PubMed][CrossRef]

5. Bersani L. Is the rectum a grave? Aids: cultural analysis/cultural activism. The University of Chicago Press 1987; 197- 222.

6. Golub SA, Starks TJ, Payton G et al. The critical role of intimacy in the sexual risk behaviors of gay and bisexual men. AIDS Behav 2012; 16: 626-32. [PubMed][CrossRef]

7. Slagstad K. Taushet er død - hva hivaktivistene lærte oss. Tidsskr Nor Legeforen 2017; 137: 903 - 7 .

[CrossRef]

8. Hvattum M. Major og Schirmers Gaustad. Tidsskr Nor Legeforen 2016; 136: 1113 - 8.

[PubMed][CrossRef]

9. Husom N. Med distriktslegen gjennom dype daler og store høyder. Tidsskr Nor Legeforen 20oo; 120: 2588 - 9 .

10. Horton R. Offline: The moribund body of medical history. Lancet 2014;384: 292. [CrossRef]

11. Vogt H, Hofmann B, Getz L. The new holism: $\mathrm{P}_{4}$ systems medicine and the medicalization of health and life itself. Med Health Care Philos 2016;19:307 - 23. [PubMed][CrossRef]

12. Jordonova L. The social construction of medical knowledge. I: Huisman F, Warner JH, red. Locating medical history. Baltimore, MD: Johns Hopkins University Press, 2006.

13. Huisman F, Warner JH. Medical histories. I: Huisman F, Warner JH, red. Locating medical history. Baltimore, MD: Johns Hopkins University Press, 2006.

14. Gradmann C. Medisinsk historie - hvorfor og hvordan? Tidsskr Nor Legeforen 2017; 137: 681.

[PubMed][CrossRef]

Publisert: 18. september 2017. Tidsskr Nor Legeforen. DOI:10.4045/tidsskr.17.0533

Mottatt 14.6.2017, godkjent 28.6.2017.

(C) Tidsskrift for Den norske legeforening 2020. Lastet ned fra tidsskriftet.no 